\title{
Development trends of the hospitality industry and domestic tourism in rural territories of the Rostov region
}

\author{
Lyudmila Kazmina ${ }^{1}$, Vadim Makarenko ${ }^{1}$, Valeria Provotorina ${ }^{1}$, and Elena Shevchenko ${ }^{1, *}$ \\ ${ }^{1}$ Don State Technical University, Gagarin Sq., 1, Rostov-on-Don, 344003, Russia
}

\begin{abstract}
The present article is concerned with development trends of the hospitality industry and domestic tourism in rural territories of the Rostov region. This article provides a review of materials related to the research problem; rural districts of the Rostov region are considered from the perspective of the development of the hospitality industry and domestic tourism. In addition, perspective events, which are able to become a basis for the development of domestic tourism in some districts, are defined.
\end{abstract}

\section{Introduction}

Today, tourism in rural territories is able to become a growth area for the tourist and recreational sector of some districts. In rural areas, a wide range of domestic tourism types, such as agritourism, ecotourism, ethnographic tourism, sport tourism, fishing, food tourism, equine tourism can be implemented.

For the tourism sector to operate in a balanced manner, it is necessary to develop the hospitality industry, which includes accommodation means, catering and trade establishments, tourist-information centers, etc.

Means of accommodation are a major component of tourism infrastructure, as accommodation is a key service in a tourism product. Due to emerging infrastructure, the development of tourist resources occurs; their attractiveness, availability for tourists and the tourist capacity of the territory are increasing. Thus, hotel services are the basis of the tourist offer, in line with rural tourism.

In this regard, the task to provide rural areas with hospitality industry facilities corresponding to the available tourist resources and capable of bringing the tourism of such areas to the new level of development seems to be especially relevant.

The purpose of the article is to analyze development trends of the hospitality industry and domestic tourism in rural territories of the Rostov region and to determine the prospects for the tourism and recreation sphere of such territories.

Main tasks of the study:

- to analyze the research basis of the issue of condition and problems related to the hospitality industry and domestic tourism in rural territories;

\footnotetext{
*Corresponding author : epetrova21@mail.ru
} 
- to consider rural territories of the Rostov region in the light of the development of the hospitality industry and domestic tourism;

- to define perspective newsworthy events, which are able to become a driver for rural tourism.

\section{Background and methods}

Domestic tourism is one of the most proffered types of tourism to support, and often to develop, regional economics. Domestic tourism is of particular importance in rural areas, because tourism is a socially significant activity for them. It contributes to the development of infrastructure, an increase in the income of local residents, a decrease in unemployment, improvement of living standards, and preservation of local culture and traditions.

In the present study, opinions of scientists as to general impact of domestic tourism on regional economics (Nguyen Phuc Canh, Su Dinh Thanh, Peng Yu, Jinhe Zhang, Yaru Wang, ChangWang, Hongmei Zhang, 2020 [1, 2]), and also of some participants of the tourism market, for example, carriers, (Kan Wai Hong Tsui, 2017 [3]) are taken into consideration.

At that, the leading role of the state in the development of rural areas through domestic tourism is noted by Chunyan Liu Xueting Dou, Jiangfeng Li, Liping A.Cai, 2020 [4]. It is said that domestic tourism in rural areas is able to reduce the the drift of young people from the land, to erase gains of rural depopulation (Otar Paresishvili, Laura Kvaratskhelia Valentina Mirzaeva, 2017 [5]).

The role of tourism in recovery of rural territories is highlighted in the papers of Isabel Dinis, Orlando Simões, Cristina Cruz, Ana Teodoro, Suyan Shen, Hao Wang, Qianhong Quan, Jian Xu, 2019 [6, 7].

Interest in rural tourism is found everywhere throughout the world. Analysis of literature sources has shown that tourism in rural territories is often high-demand among elderly consumers, who travel for reasons of nostalgia (P.Christou, A.Farmaki, G.Evangelou, 2018 [8]), a desire to be in an ecologically balanced environment (Fereshteh Pezeshki, Saeid Ardekani, Masood Khodadadi, Seyed Mahdi Alhosseini Almodarresi Faride Sadat Hosseini, Clifford Lewis, Steve D'Alessandro 2019 [9, 10]). In China, a great attention is paid to visits of elderly people to rural areas for purposes of tourism and recreation. It is supported by studies of Yu Pan, Xiaoyu Wang, Chris Ryan, Jiaying Lyu, Huan Huang, Zhenxing Mao, 2021 [11, 12].

At that the studies show that elderly people are not the only consumer group interested in rural tourism. The experience of various countries demonstrates that young people and families with children are interested in domestic tourism in rural areas too (Celeste Eusébio, Maria João Carneiro, Elisabeth Kastenholz, Elisabete Figueiredo, DiogoSoares da Silva, 2017 [13]). In the present paper, studies of Paula Remoaldo, Jaime Serra, Noémi Marujo Juliana Alves, Alexandra Gonçalves, Sónia Cabeça, Nancy Duxbury, 2020, related to establishing the motives of visits to tourist destinations in rural areas, are taken into consideration [14].

The experience in researching tourism in rural areas in the sense of its sustainable development is taken into account. A review of various methodologies for estimating the development of tourism in rural areas is carried out. In the present paper, we note a need to establish strengths and weaknesses, as well as opportunities and threats related to the tourism development, especially in protected natural areas (nature reserves, wildlife areas, national parks), as tourism may have both positive and negative impact on territories ( Dušan Ristić, Danijela Vukoičić, Miroljub Milinčić, 2019 [15]). 
Sustainable development of tourism is subject to the development of a certain type of tourism, which is non-environment-damaging. Some scientists, such as Jing huiLi, Yang Bai, Juha M.Alatalo, highlight an intimate connection between tourism in rural areas located toward popular large natural sites and environmental degradation, 2020 [16]. At the same time, a need for a well-reasoned policy in the course of planning tourism in natural areas is underlined.

Within the framework of the sustainable development of rural territories through tourism, many infrastructure elements are to be extensively reconstructed, as discussed in the study of Chunliu Gao, Li Cheng, 2020, [17]. The development of domestic tourism in rural areas will result in new employment opportunities, seized by local residents; and it will create an inflow of labor forces from other territories (Jiuxia Sun, Ling Ling, Zhuowei (Joy) Huang, 2020 [18]).

A significant point of the study of the domestic tourism development in rural areas is availability of accommodation means. Scientific literature distinguishes the typology of hotels depending on their location and tourism sector. In rural areas, discrepancies in position of hotels on the basis of seasonality, tourism intensity, and tourism types occur (Filipe Batista e Silva, Ricardo Barranco, Paola Proietti, Cristian Pigaiani, Carlo Lavalle, 2020 [19]).

In the present study, recommendations regarding technologies and algorithms of the domestic tourism development in rural territories with due regard to their geographical location and key seasonal differences described by Xiaojian Zhang, Limin Yu, Minjuan Wang, Wanlin Gao, 2018 [20] are taken into account.

Approach to researching rural hotels and tourist organizations, providing services for domestic tourists, is taken into consideration (Cátia Jesus, Mário Franco, 2016 [21]). It provides for obtaining data on fundamental discrepancy between urban and rural tourism.

Today, COVID-19 pandemia has tourism on the run around the world. This has become one of the determining factors for all types of tourism. There are few scientific literature sources that would contain comprehensive information on the development of tourism in such conditions. However, the paper of Fatma Altuntas, Mehmet Sahin Gok, 2021 [22] contains a take on further development of the tourism and hospitality sphere in the context of quarantine restrictions.

For the sake of completeness, the authors analyzed the papers on domestic tourism in rural areas in Russia. For example, it was found that rural tourism is on the increase. However, despite the strong potential, this type of tourism is plagued by a number of problems, for example, the image of the destination, the infrastructure development, the availability and level of qualifications of personnel, state support, quality control, promotion and advertising of domestic tourism (Lidia Andrades, Frederic Dimanche, 2017 [23]).

As for domestic tourism directly in the study area - the Rostov region, it is important to present the results of researches of L.N. Kazmina, V.S. Makarenko, V.V. Provotorina, T.N. Grigorenko, E. Shevchenko, 2020 [24, 25]. In these papers, an analysis of the leading factors of the tourism development in the region, an assessment of the tourist and recreational potential and conclusions of the need to develop an optimal business model of tourismwith due regard to the specifics of the region, are presented.

The research methodology is based on the application of the following mwthods:

- comparative analysis, used to compare the development of the hospitality industry in some rural areas of the Rostov region;

- statistical analysis, involving the identification and further analysis of the accommodation means quantity and the hospitality bed availability of individual enterprises, 
- descriptive analysis, used to characterize modern trends in the development of domestic tourism and the hospitality industry in rural areas;

- prospective analysis, applied to identify priorities for the development of tourism and the hospitality industry in rural areas of the Rostov region.

\section{Results}

The Rostov region is characterized by a rather high level of urbanization $-68.4 \%$, therefore, most of the region's residents have an issue with the urban environment - noise and environmental pollution, physical and mental fatigue and many others. In such a situation, it seems necessary to have places for rest and recreation near urban agglomerations, which could be regularly visited, in particular, as city breaks.

Rural areas of the Rostov region can serve these purposes. They have a tourist potential, expressed by historical heritage, ethnic diversity, and cultural traditions. Rural areas can be a basis for the development of agritourism, ecological, ethnic, food, sport tourism.

For the balanced development of tourism in rural areas, it is necessary to operate the hospitality industry at the proper level and to create an appropriate tourist infrastructure. Infrastructure is an important resource component of the tourism and hospitality industry and is a complex of structures, networks and establishments for serving tourists and ensuring the functioning of the tourism and recreation sector.

The objects of the tourist infrastructure include transport networks, accommodation means, catering, trade, entertainment establishments, and tourist information centers. The healthy development of the tourist infrastructure in the region is the only one that will facilitate incoming tours on a regular basis.

In many rural areas of the Rostov region, the development of tourist infrastructure facilities should be considered insufficient for the healthy development of the recreational sphere. There are practically non-existent means of accommodation capable to take significant number of guests in all year round, which makes it impossible to arrange tourists' staying for several days.

In the Rostov region, there are about 1000 accommodation means, while a significant part, about 700, are urban. Thus, rural accommodation means of various types account for about $30 \%$ of their total, with an average capacity of 15 rooms. The total hospitality bed availability in rural hotels is 1,700 rooms, about 5,000 beds.

As an example, statistics on the number of accommodation means in rural municipal areas of the region are given (Table 1).

As is obvious, a significant share of rural municipal districts of the Rostov region (17 out of 43 , which is $40 \%$ ), have 1 or 2 accommodation means (the Milyutinskaya district is the only one in the region where there are no accommodation means).

Such a low availability of hotels prevents the arrangement of group tours to these rural areas and lays tour operators under necessity to be restricted to an excursion program without overnight accommodation at the place of stay. Without constructing additional accommodation means in these areas, planning future tours is also not possible.

It should be noted that the regions with the lowest availability of hotels are located mainly in the north, east and south-east of the region, far from its administrative center. 
Table 1. Classification of rural areas of the Rostov region according to the quantity of accommodation means.

\begin{tabular}{|c|c|l|}
\hline $\begin{array}{c}\text { Item } \\
\text { No. }\end{array}$ & $\begin{array}{c}\text { Quantity of } \\
\text { accommodation } \\
\text { means }\end{array}$ & \multicolumn{1}{|c|}{ Rural areas } \\
\hline 1 & $0-2$ & $\begin{array}{l}\text { Verkhnedonskoy, Dubovskoye, Zavetnoye, Kagalnitskaya, } \\
\text { Kashary, Konstantinovsk, Kuibyshevo, Milyutinskaya, } \\
\text { Morozovsk, Oblivskaya, Peschanokopskoye, Remontnoye, } \\
\text { Rodionovo-Nesvetayskaya, Sovietskaya, Tatsinskaya, } \\
\text { Tselina, Chertkovo }\end{array}$ \\
\hline 2 & $3-5$ & $\begin{array}{l}\text { Bokovskaya, Egorlykskaya, Zernograd, Zimovniki, } \\
\text { Martynovsky, Matveyev-Kurgan, Oktyabrsky, Orlovsky, } \\
\text { Proletarsk, Tarasovsky, Tsimlyansk }\end{array}$ \\
\hline 3 & $6-8$ & Bagaevskaya \\
\hline 4 & $9-11$ & $\begin{array}{l}\text { Vesely, Volgodonskoy, Kamenskaya, Neklinovsky, Salsk, } \\
\text { Ust-Donetsky }\end{array}$ \\
\hline 5 & more than 11 & $\begin{array}{l}\text { Azov, Aksay, Belaya Kalitva, Krasnyi Sulin, Millerovo, } \\
\text { Myasnikovsky, Semikarakorsk, Sholokhovsky }\end{array}$ \\
\hline
\end{tabular}

Eleven districts of the region (23\%) have from 3 to 5 accommodation means. Such districts include Bokovskaya, Egorlykskaya, Zernograd, Zimovniki, Martynovsky, Matveyev-Kurgan, Oktyabrsky, Orlovsky, Proletarsk, Tarasovsky, Tsimlyansk, located mainly in the south, southeast and north of the region. Of these areas, only Oktyabrsky is located near the Rostov agglomeration. Such availability of accommodation means allows for medium-sized group tours (10-15 people).

The Azov, Aksay, Belaya Kalitva, Krasnyi Sulin, Millerovo, Myasnikovsky, Semikarakorsk, Sholokhovsky districts are the best provided with accommodation means in the region. Such areas mainly include those that have appropriate tourist resources or located near the administrative center of the region. In these areas, an excursion program is implemented, newsworthy events are held, but tours are nearly non-existent (even city breaks are underrepresented).

At the same time, many rural areas have adequate touristic resources so that to be included in a program of various orientation. These are such districts as Ust-Donetsky (ethnographic tourism), Myasnikovsky (archaeological, ethnographic tourism), Bagaevskaya (agritourism, fishing tourism), Semikarakorsk (ethnographic tourism, arts and crafts), Orlovsky (ecotourism), Proletarsk (equine tourism), Salsk (fishing), Tsimlyansk (ethnographic, water tourism), Vyoshensky (ethnographic tourism, ecotourism).

To make the available tourist resources more popular and to attract guests, it is relevant to arrange and hold traditional newsworthy events. Such events should both reflect the specifics of the region and be attractive to tourists. A list of possible activities in selected rural areas of the region is shown in Table 2.

Table 2. Potential newsworthy events in rural areas of the Rostov region.

\begin{tabular}{|l|l|l|l|l|}
\hline $\mathbf{N}$ & Regions & Settlements & Type & \multicolumn{1}{c|}{ Events } \\
\hline 1 & Aksay & Elizavetinskaya & ethnographic & Cossackdom Festival \\
\hline 2 & Azov & Starocherkasskaya & $\begin{array}{l}\text { ethnographic } \\
\text { fishing }\end{array}$ & $\begin{array}{l}\text { Cossack Folklore Festival } \\
\text { Day of the Chebak }\end{array}$ \\
\hline 3 & Bagaevskaya & Bagaevskaya & $\begin{array}{l}\text { farm } \\
\text { ecological }\end{array}$ & $\begin{array}{l}\text { Cucumber's Day } \\
\text { Arbor Day }\end{array}$ \\
\hline 4 & Belaya Kalitva & Pogorelov & ethnographic & Kayal readings \\
\hline 5 & Volgodonsk & Romanovskaya & $\begin{array}{l}\text { river (hunting and fishing), } \\
\text { ethnotourism }\end{array}$ & $\begin{array}{l}\text { Don Cooking Day } \\
\text { Young Wine Day }\end{array}$ \\
\hline 6 & Yegorlykskaya & Yegorlykskaya & farm & Harvest Festival \\
\hline
\end{tabular}




\begin{tabular}{|l|l|l|l|l|}
\hline 7 & Zernograd & Gulyai-Borisovka & wild-honey farming & Bees' Day \\
\hline 8 & Krasnyi Sulin & Zaytsevka & sport & region spartakiada games \\
\hline 9 & Myasnikovsky & Chaltyr' & $\begin{array}{l}\text { ethnographic } \\
\text { archaeological }\end{array}$ & $\begin{array}{l}\text { Armenian Culture Day } \\
\text { Tanais Day }\end{array}$ \\
\hline 10 & Orlovsky & Orlovsky & ecological & Glorified Steppe Festival \\
\hline 11 & Peschanokopskoye & Peschanokopskoye & sheep-breeding & Herder's Day \\
\hline 12 & Proletarsky & Buddyenovskaya & horse-riding & Horse-Riding Festival \\
\hline 13 & Salsk & Novyi Manych & fishing & Manych Day \\
\hline 14 & Semikarakorsk & Semikarakorsk & $\begin{array}{l}\text { ethnographic } \\
\text { farm }\end{array}$ & $\begin{array}{l}\text { Zakrutkinskaya Spring } \\
\text { Festival }\end{array}$ \\
\hline 15 & Ust-Donetsky & $\begin{array}{l}\text { Melikhovskaya, } \\
\text { Razdorskaya }\end{array}$ & $\begin{array}{l}\text { ethnographic } \\
\text { Cossack Day }\end{array}$ \\
\hline 16 & Tsimlansk & $\begin{array}{l}\text { Tsimlansk, } \\
\text { Novotsimlyanskaya }\end{array}$ & $\begin{array}{l}\text { ethnotourism } \\
\text { fishing }\end{array}$ & $\begin{array}{l}\text { Don Wine Festival } \\
\text { Don Ukha Festival }\end{array}$ \\
\hline 17 & Sholokhovsky & Veshenskaya & $\begin{array}{l}\text { ethnographic } \\
\text { ecological }\end{array}$ & $\begin{array}{l}\text { Sholokhov Spring Festival } \\
\text { Don Wides Festival }\end{array}$ \\
\hline
\end{tabular}

Based on these activities, it is possible to develop a tourism brand for the respective areas. In each individual case, the brand will reflect the specifics of the territory, make the area recognizable, trigger the corresponding associations among tourists (Cossackdom, fishing, sports, etc.) and increase the tourist attractiveness of the territory.

The specified newsworthy events can become a framework for the development of elements of the tourist infrastructure. Holding regular events will make it possible to attract tourists both from other districts and cities of the Rostov region, and from other regions of Russia.

But this is possible only with an appropriate level of development of the hospitality industry as a whole, an increase in hospitality bed availability, a variety of food and trade establishments (including those selling souvenir products.

\section{Discussion}

Domestic tourism in rural territories is a driver for their development, a tool for generating employment and new opportunities for small and medium rural enterprises. The development of rural tours can become an important component of the transition to sustainable tourism development in the Rostov region.

Nevertheless, a comprehensive expanding of domestic tourism in rural areas is impossible without the intentional development of the hospitality industry, focused on the needs of each specific territory.

As one of the lines of further development of the hospitality industry in rural areas, it is planned to build accommodation facilities. At the same time, it is important that in an area having significant tourist resources, there are accommodation facilities of various categories to receive all possible segments of tourists.

Availability of catering establishments reflecting the culinary specifics of the area and providing opportunities for tasting various dishes and drinks is relevant too. Thus, the food industry in the area will become not only an important element of the hospitality industry, but will also blend in with the program of domestic tours.

The accompanying components of the hospitality industry in rural areas should also be trade enterprises, primarily those selling souvenir products. Such products should reflect the specifics of the area, be visually attractive, unique and affordably priced. These can be samples of craftwork, stylized bottles of wine, models of remarkable buildings, game souvenirs for children. 
An important element in the development of the hospitality industry is tourist information centers, where tourists can get maps of the area, travel guides and other necessary information.

The listed components of the hospitality industry can become elements of tourist clusters in rural areas. On the basis of such clusters, it is possible to set strategic objectives and tasks for the development of tourism in rural areas, to arrange various tours, to improve the image component of the region's hospitality industry.

The specialization of rural areas in specific types of tourism will make it possible to implement a differentiated approach to the formation of programs for the development of the tourism industry and planning the implementation of different tours in the respective territories. The distribution of rural districts by a corresponding touristic niche will facilitate their harmonious co-development without undue competition within separate sectors.

An additional social and economic effect of the development of tourism and the hospitality industry in rural areas of the region will be increased employment opportunities, an increase in the income of the population, an inflow of long-term investments.

\section{Conclusions}

Following the conducted research a number of conclusions can be made. Today tourism in rural territories of the Rostov region is able to become an upcoming trend for urban residents, as well as for guests from nearby administrative subjects. Special mention should go to city breaks.

The development of tourism in rural areas can be ensured at a certain level of the hospitality industry, in particular, the infrastructure availability - accommodation means, catering establishments, trade, tourist information centers, etc.

At the present time, the level of development of the hospitality industry in various rural areas, especially those remote from the administrative center of the region, is insufficient for the regular accommodation of tourist groups.

Rural areas of the region have a certain tourist potential, expressed by their natural sites, cultural and historical heritage, ethnic and gastronomic traditions, arts and crafts. Based on the tourism resources of each area, regular newsworthy events can be held to attract tourists.

The specified events can become a basis to develop tourism and the hospitality industry and to form tourist clusters of a certain orientation in rural areas and become a growth area for the development of tourism in the region as a whole.

The specialization of individual rural districts in certain types of tourism will make it possible to use a differentiated approach to the formation of tourism development programs for the Rostov region, as well as to become a basis for the adoption of tourism development programs for each municipal district with a focus on the development of those types of tourism that can become the basis for the development of rural areas.

The development of the hospitality industry and tourism in rural territories may have a positive social and economic effect resulted from providing employment opportunities, an increase in gross regional product, optimization of tourist infrastructure, a rise in standards and quality of life of local population.

\section{References}

1. Nguyen Phuc Canh, Su Dinh Thanh, Annals of Tourism Research 85, 103063 (2020) doi.org/10.1016/j.annals.2020.103063 
2. Peng Yu, Jinhe Zhang, Yaru Wang, Chang Wang, Hongmei Zhang, Science of The Total Environment 748, 141099 (2020) doi.org/10.1016/j.scitotenv.2020.141099

3. Kan Wai Hong Tsui, Tourism Management 60, 390-403 (2017) https://doi.org/10.1016/j.tourman.2016.10.013

4. Chunyan Liu, Xueting Dou, Jiang feng Li, Liping A. Cai, Journal of Rural Studies 79, 177-188 (2020) doi.org/10.1016/j.jrurstud.2020.08.046

5. O. Paresishvili, L. Kvaratskhelia, V. Mirzaeva, Annals of Agrarian Science 15(3), 344348 (2017) doi.org/10.1016/j.aasci.2017.07.008

6. I. Dinis, O. Simões, C. Cruz, A. Teodoro, Journal of Rural Studies 72, 92-103 (2019) doi.org/10.1016/j.jrurstud.2019.10.002

7. S. Shen, H. Wang, Qianhong Quan, Jian Xu, Tourism Management Perspectives 30, 98-106 (2019) doi.org/10.1016/j.tmp.2019.02.006

8. P. Christou, A. Farmaki, G. Evangelou, Tourism Management 69, 42-51 (2018) doi.org/10.1016/j.tourman.2018.05.010

9. F. Pezeshki, S. Ardekani, M. Khodadadi, S. Mahdi Alhosseini Almodarresi Faride Sadat Hosseini, Journal of Hospitality and Tourism Management, 39, 9-19 (2019) doi.org/10.1016/j.jhtm.2019.01.008

10. C. Lewis, S. D'Alessandro, Tourism Management Perspectives 32, 100574 (2019) doi.org/10.1016/j.tmp.2019.100574

11. Jiaying Lyu, Huan Huang, Zhenxing Mao, Journal of Destination Marketing \& Management 19, 100552 (2021) doi.org/10.1016/j.jdmm.2020.100552

12. Yu Pan, Xiaoyu Wang, Chris Ryan, Journal of Hospitality and Tourism Management 46, 134-143 (2021) doi.org/10.1016/j.jhtm.2020.09.010

13. C. Eusébio, M. João Carneiro, E. Kastenholz et al., Journal of Hospitality and Tourism Management 31, 197-210 (2017) doi.org/10.1016/j.jhtm.2016.12.006

14. P. Remoaldo, J. Serra, N. Marujo Juliana Alves et al., Tourism Management Perspectives 36, 100746 (2020) doi.org/10.1016/j.tmp.2020.100746

15. D. Ristić, D. Vukoičić, M. Milinčić, Land Use Policy 89, 104231 (2019) doi.org/10.1016/j.landusepol.2019.104231

16. Jing hui Li, Yang Bai, Juha M. Alatalo, Ecosystem Services 42, 101081 (2020) doi.org/10.1016/j.ecoser.2020.101081

17. Chunliu Gao, Li Cheng, Land Use Policy 95, 104609 (2020) doi.org/10.1016/j.landusepol.2020.104609

18. Jiuxia Sun, Ling Ling, Zhuowei (Joy) Huang, Annals of Tourism Research 84, 102972 (2020) doi.org/10.1016/j.annals.2020.102972

19. F. Batista e Silva, R. Barranco, P. Proietti, C. Pigaiani, C. Lavalle, Annals of Tourism Research 4, 103077 (2020) doi.org/10.1016/j.annals.2020.103077

20. Xiaojian Zhang, Limin Yu, Minjuan Wang, Wanlin Gao, Pattern Recognition Letters 31, 10024 (2018) doi.org/10.1016/j.patrec.2018.12.022

21. C. Jesus, M. Franco, Journal of Hospitality and Tourism Management 29, 165-175 (2016) doi.org/10.1016/j.jhtm.2016.07.005

22. F. Altuntas, M. Sahin Gok, International Journal of Hospitality Management 92, 102719 (2021) doi.org/10.1016/j.ijhm.2020.102719

23. L. Andrades, F. Dimanche, Tourism Management 62, 360-376 (2017) 
24. L.N. Kazmina, V.S. Makarenko, V.V. Provotorina, T.N. Grigorenko, International Journal of Economics and Business Administration 7, 510-520 (2019) doi: 10.35808/ijeba/297

25. L. Kazmina, V. Makarenko, V. Provotorina, E. Shevchenko, E3S Web of Conferences 175, $10001(2020)$ 